\title{
FRIEDREICH'S ATAXIA: CLINICAL AND MOLECULAR STUDY OF 25 BRAZILIAN CASES
}

Lilian M. J. Albano, Mayana Zatz, Chong A. Kim, Débora Bertola, Sofia M. M. Sugayama, Maria Joaquina Marques-Dias, Fernando Kok, Ivan Ferraretto, Sérgio Rosemberg, Sergio Cocozza and Antonella Monticelli 56(5):143-148, 2001.

Introduction: Friedreich's ataxia is a neurodegenerative disorder whose clinical diagnostic criteria for typical cases basically include: a) early age of onset ( $<20$ or 25 years), b) autosomal recessive inheritance, c) progressive ataxia of limbs and gait, and d) absence of lower limb tendon reflexes.

Methods: We studied the frequency and the size of expanded GAA and their influence on neurologic findings, age at onset, and disease progression in 25 Brazilian patients with clinical diagnosis of Friedreich's ataxia - 19 typical and 6 atypical — using a long-range PCR test.

Results: Abnormalities in cerebellar signs, in electrocardiography, and pes cavus occurred more frequently in typical cases; however, plantar response and speech were more frequently normal in this group when the both typical and atypical cases were compared. Homozygous GAA expansion repeats were detected in 17 cases (68\%) - all typical cases. In 8 patients (32\%) $(6$ atypical and 2 typical), no expansion was observed, ruling out the diagnosis of Friedreich's ataxia. In cases with GAA expansions, foot deformity, cardiac abnormalities, and some neurologic findings occurred more frequently; however, abnormalities in cranial nerves and in tomographic findings were detected less frequently than in patients without GAA expansions.

Discussion: Molecular analysis was imperative for the diagnosis of Friedreich's ataxia, not only for typical cases but also for atypical ones. There was no genotype-phenotype correlation. Diagnosis based only on clinical findings is limited; however, it aids in better screening for suspected cases that should be tested. Evaluation for vitamin E deficiency is recommended, especially in cases without GAA expansion.

DESCRIPTORS: Friedreich's ataxia. Trinucleotide expansion repeats. GAA expansion.

Friedreich's ataxia (FA) (OMIM $277460)^{23}$, a neurodegenerative disorder, is the most frequent form of hereditary ataxia, with a prevalence of 1:50,000. Clinical diagnostic criteria for typical cases basically include: a) early age of onset $<20^{16}$ or 25 years ${ }^{17}$, b) autosomal recessive inheritance, c) progressive ataxia of limbs and gait, and d) absence of lower limb tendon reflexes.

Chamberlain et al. $(1988)^{8}$ mapped the Friedreich's ataxia gene to chromosome 9 , which was subsequently con- firmed ${ }^{15}$. Later, recombinant events ${ }^{3}$ allowed the successive narrowing of the candidate region ${ }^{7,10,22,26}$. Campuzano et al. $(1996)^{6}$ detected in about $96 \%$ of

From the Genetic Unit, Infant Neurological Unit of the Children's Institute of Hospital das Clínicas, Department of Neurology of Hospital das Clínicas, Faculty of Medicine, University of São Paulo; Department of Biology of the Bioscience Institute; Handicap Children's Association (A.A.C.D); Department of Neurology of the Santa Casa de Misericórdia, and Biology and Pathology Cellular and Molecular Department, Frederick II University of Naples, Italy.
Friedreich's ataxia patients an expanded GAA (guanine, adenine, and adenine) trinucleotide repeat in intron 1 of the gene X25 (with 7 exons - 1 to $5 \mathrm{a}, 5 \mathrm{~b}$, and 6 - spanning $95 \mathrm{~kb}$ of genomic DNA) that encodes a 210 amino acid protein, frataxin, whose function is unknown.

Absence of deep tendon reflexes in lower limbs has been included in the diagnostic criteria both by the Geoffroy et al. (1976) and Harding (1981) ${ }^{16,17}$; however, clinical variability has been reported $^{11,14}$, especially related to the 
age at onset and to the progression of the disease. These atypical forms, which do not entirely fulfill their criteria and are known in the literature as FARR (Friedreich's $A$ taxia with Retained Reflexes) and LOFA (Late $O$ nset of Friedreich $A$ taxia), can carry the same mutational mechanism observed in $\mathrm{FA}^{25}$.

Since we believe that it is important to evaluate and reinforce the clinical spectrum of the FA phenotype, we analyzed a genotype-phenotype correlation, studying the frequency and the size of expanded GAA repeats and their influence on neurologic findings, age at onset, and progression of the disease in 25 Brazilian patients with clinical diagnosis of FA, including 6 with an atypical phenotype.

\section{PATIENTS AND METHODS}

\section{Patients}

We studied 25 Brazilian patients (13 females and 12 males) from 15 unrelated families with clinical diagnosis of FA regarding their clinical and molecular aspects. We basically adopted the clinical criteria of Geoffroy et al. (1976) ${ }^{16}$ and Harding (1981) ${ }^{17}$ for typical cases, but we also included patients with the presence of unexpected deep tendon reflexes, since the FA phenotype is broader than previously described $^{11,14}$. We performed clinical and laboratory investigations, such as: a) fasting glucose test (GLU), b) electrocardiogram (ECG), c) echocardiogram (ECO), and d) cranial and/or column computed tomographic (CT) images.

\section{Methods}

\section{GAA repeat analysis}

DNA from each patient was extracted from EDTA-treated blood samples $^{21}$, and the $(\mathrm{GAA})_{\mathrm{n}}$ repeat length in the first intron of the gene X25 was kindly analyzed in Naples, Italy, with a polymerase chain reaction (PCR) according the method of Filla et al. $(1996)^{14}$.

\section{RESULTS}

Our clinical analysis, before the molecular diagnosis, revealed that typical cases, when compared with the atypical cases, more often showed some findings of cerebellar dysfunction $\quad\left(p=0.0001^{*}\right), \quad$ areflexia $\left(p=0.0012^{*}\right)$, pes cavus $\left(p=0.0022^{*}\right)$, and abnormalities in ECG (ventricular repolarization) $\left(\mathrm{p}=0.0196^{*}\right)$; less frequently found were muscle trophism $\left(\mathrm{p}=0.0593^{*}\right)$ and CT image abnormalities $\left(p=0.0350^{*}\right)$. Extensor plantar responses $\left(p=0.0565^{*}\right)$ and abnormalities in speech $\left(\mathrm{p}=0.0565^{*}\right)$ were observed less frequently in cases in which the age at onset was less than 10 years and least frequently in cases in which there were abnormalities in ECG/ECO $\left(p=0.0392^{*}\right)$.

We found homozygous GAA expansion repeats in intron 1 of the gene
X25 in 17 out of 25 ataxia patients (68\%) - all typical cases. Eight patients whose clinical diagnosis had been FA did not present any GAA expansion (32\%). Therefore, they did not have FA. This group was comprised of 6 atypical cases and 2 typical cases.

The (GAA) repeats on FA patients was observed in both alleles, ranging from 291 to 1091 GAA motifs (Fig. 1). Thus, we have not observed only one expanded allele on one chromosome with the other presenting a normal range of expansion repeats. The mean value of expanded alleles was 636 repeats for allele 1 (smaller allele) and 773 for allele 2 (larger allele).

Patients with GAA expansion repeats, when compared with those without GAA expansion, more frequently showed extensor plantar responses $\left(p=0.0055^{*}\right)$ and abnormalities in: a) deep tendon reflexes $\left(p=0.0055^{*}, b\right)$ postural and vibratory sense $\left.\left(p=0.0010^{*}\right), c\right)$ feet (pes cavus) $\left(\mathrm{p}=0.0010^{*}\right)$, and $\left.\mathrm{d}\right)$ ECG findings $\left(p=0.0049^{*}\right)$. On the other hand, abnormalities in cranial nerves $(\mathrm{p}=0.0099 *)$ and in CT findings $\left(\mathrm{p}=0.0350^{*}\right)$ were more common in patients without ex-

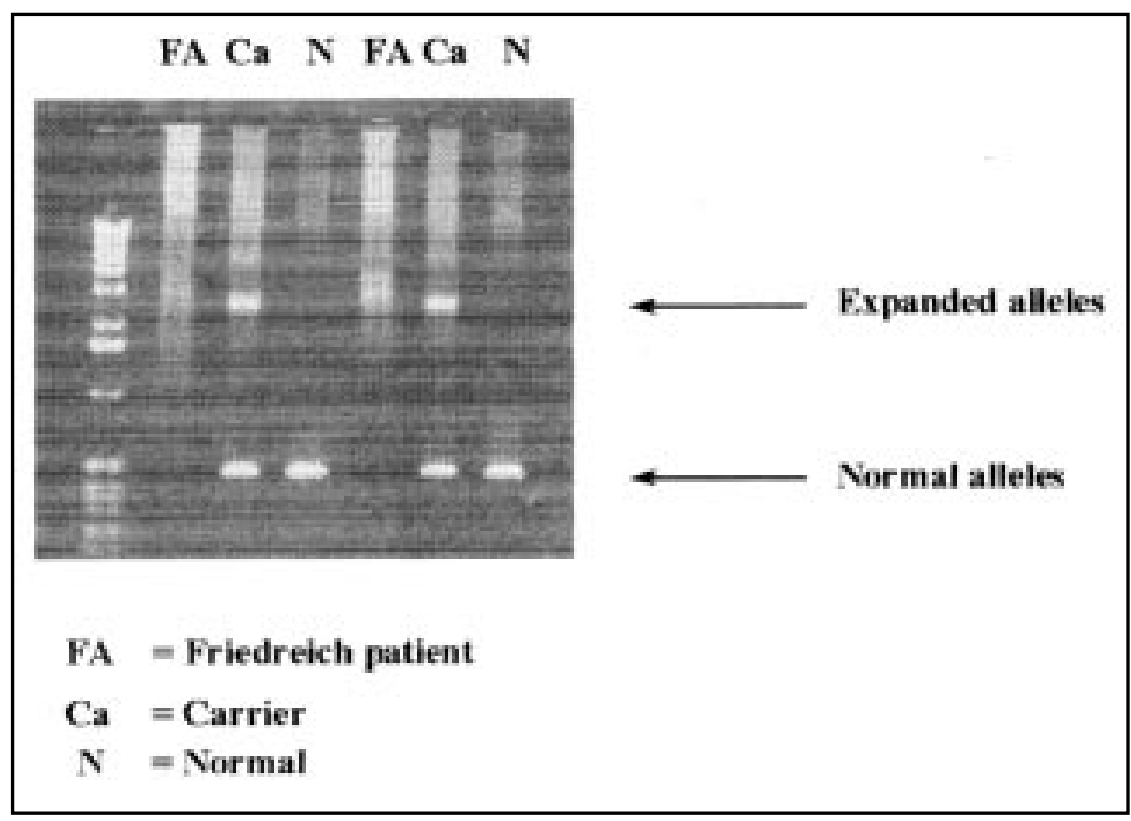

Figure 1 - Gel images of GAA expansion of Friedreich's ataxia patients, heterozygotes, and normal controls. 
pansion. No statistically significant difference was observed between the variables studied when we compared typical cases with GAA expansion and typical cases without GAA expansion repeats.

\section{DISCUSSION}

The expansion of trinucleotide repeat sequences is the underlying cause of many neurodegenerative diseases, including myotonic dystrophy, fragile $\mathrm{X}$ syndrome, Huntington disease, FA, and several spinocerebellar ataxias. FA has interesting points that should be emphasized once new boundaries were established: a) this mutational mechanism constitutes the first one found in a disease with a recessive pattern of inheritance; b) this is the first time that these dynamic expansions have been detected in an intronic region and the triplet involved is comprised of GAA repeats; and finally c) the DNA molecule in Friedreich's ataxia assumes triplex structures ${ }^{24,29}$.

Our 17 patients that were homozygous for an expanded (GAA) repeat in the X25 gene had: a) onset of the disease before the age of 20 years, b) progressive ataxia of gait and limbs, c) lower limb areflexia, and d) abnormalities in postural and vibratory sense.
The mean age at onset, death, becoming wheelchair-bound, and duration of the disease (Table 1) as well as clinical and laboratories findings (Table 2) were compared to the data in the literature.

The size of GAA expansion observed in our patients, ranging from 291 to 1091, reflects the instability of this expansion during transmission.

We analyzed the size of alleles in relation to: a) the age at onset, b) the age at which patients became wheelchair-bound, c) presence of abnormalities in ECG and/or ECO, and d) the duration of the disease. A statistical significance could be detected only for the difference between the size of allele 1 and allele 2; we were unable to establish any genotype-phenotype correlation. Within the group of typical cases, the same variables studied did not reveal any statistically significant differences when we considered the cases with GAA expansion compared with the cases without it.

By applying the clinical criteria described by Geoffroy et al. $(1976)^{16}$ and Harding (1981) ${ }^{17}$, we detected a homozygous GAA expansion in $89.5 \%$ $(17 / 19)$ of all patients who met this criteria. We ruled out FA in the 2 typical patients without GAA expansion, so the possibility of vitamin E deficiency should be considered in these cases.

Although there are reports in the literature of atypical cases with GAA expansion repeats, none of our atypical cases had them, ruling out the diagnosis of FA in these patients ${ }^{9,28}$.

Therefore, molecular analysis is essential for confirming the diagnosis of FA, not only in typical cases, but especially in atypical ones, contributing to

Table 1 - Frequency of mean ages at disease onset, becoming wheelchair-bound, and death, as well as the disease's duration in the literature and in the present study.

\begin{tabular}{lcccc}
\hline REFERENCES & $\begin{array}{c}\text { Age of Onset } \\
\text { (years) }\end{array}$ & $\begin{array}{c}\text { Wheelchair- } \\
\text { bound }\end{array}$ & $\begin{array}{c}\text { Death } \\
\text { Duration } \\
\text { (years) }\end{array}$ \\
\hline Bell \& Carmichael (1939) & 12 & 16 & 26 & 16 \\
Thóren (1962) & 6 & & 29 & \\
Boyer et al (1962) & 8 & & 37 & 24 \\
Dick \& Lambert (1968) & 8 & & 31 & 21 \\
Hewer (1968) & 9 & & 12 \\
Andermann et al (1976) & 8 & & - & 11 \\
Geoffroy et al (1976) & 12 & 21 & & \\
Filla et al (1990) & 10 & & & \\
Present study (2001) & & & & \\
\hline
\end{tabular}

Table 2 - Frequency (\%) of some findings of the typical form of Friedreich's ataxia ${ }^{16,17}$ according to the literature and the present study (with GAA trinucleotide repeats)

\begin{tabular}{|c|c|c|c|c|c|c|c|c|c|}
\hline REFERENCES & 2 & 16 & 17 & 13 & 19 & 11 & 20 & 27 & Present study \\
\hline Ataxia & 100 & 100 & $63 \#$ & 84 & 100 & 100 & 100 & 100 & 100 \\
\hline Areflexia & 80 & 100 & 74 & 100 & 100 & 88 & 87 & 100 & 100 \\
\hline Dysarthria & 93 & 100 & 96 & 84 & 100 & 91 & 91 & 100 & 88 \\
\hline Extensor plantar Responses & 43 & 97 & 99 & 75 & 69 & 79 & 96 & 100 & 94 \\
\hline Position and vibratory sense & 100 & & $\sim 100 \S$ & 91 & & 78 & 87 & 93 & 100 \\
\hline Foot deformity & 83 & 97 & 55 & 90 & 54 & 55 & & 86 & 94 \\
\hline Scoliosis & 83 & 91 & 79 & 94 & 77 & 60 & & 96 & 94 \\
\hline Abnormalities in ECG & & & 75 & 80 & 62 & & 77 & 88 & 100 \\
\hline Abnormalities in ECO & & & & 34 & & 63 & & 79 & 22 \\
\hline Diabetes & - & 10 & 14 & 15 & & - & & 0 & 0 \\
\hline Nystagmus & & 45 & 20 & 29 & & 40 & & 37 & 18 \\
\hline Hearing loss & & 24 & 8 & - & & 13 & & 47 & 6 \\
\hline
\end{tabular}

\# Ataxia of upper limbs was universal, and ataxia of the lower limbs could not be detected in some patients, because of the severity of their muscle weakness.

$\S$ Sensorial loss after 25 years of age affects about $100 \%$ of the cases; and in the first five years, $50 \%$ show abnormalities in postural perception. 
adequate genetic counseling for the recessive and sporadic cerebellar ataxias.

\section{ACKNOWLEDGEMENTS}

We are extremely grateful to the kindness and promptness of the "Laboratório do Dipartimento di Biologia e Patologia Cellutare e Moleculare", specially Dra Antonella Monticelli and Dr. Sérgio Cocozza, in performing our direct molecular diag- nosis. We wish to also thank Drs. Telma Okay and Roberto R. Junior of the Laboratory of the Children's Institute, for DNA extracting. We would like to thank Drs. Lúcio Coelho Miranda, Maria Bernardete Dutra Resende, Anna Lecticia R. Pinto, José Albino da Paz, Suely Kazue Marie, Álvaro Skola and Javier Toledano Beteta, for their neurologic assistance; We are grateful to Drs. Silvana Angelino Dório Nishioka, Regina Lúcia Moysés, Jaqueline Wagenführ and Maria Lúcia Passarelli for their cardiac evaluations; We are also grateful to Dr. Jorge David Aivazoglow Carneiro for referring one family with four affected members to us and to Cesar Abe for giving us the papers of the collaborative study in Quebec. The statistical analysis was performed by Drs. Neil Ferreira Novo and Yára Juliano. We wish finally, to thank Drs. Cláudio Leone and Ulisses Dória Filho for their useful comments and suggestions.
ALBANO LMJ e col. - Ataxia de Friedreich: estudo clínico e molecular de 25 pacientes. Rev. Hosp. Clín. Fac. Med. S. Paulo 56(5): 143-148, 2001.

Introdução: A ataxia de Friedreich é uma doença neurodegenerativa e os critérios clínicos diagnósticos para os casos típicos incluem: a) idade de início precoce ( $<20$ ou 25 anos); b) herança autossômica recessiva; c) ataxia progressiva; e d) abolição dos reflexos tendinosos profundos.
Métodos: Estudou-se a freqüência e o tamanho das expansões GAA e a sua influência nos achados neurológicos, idade de início e progressão da doença, em 25 pacientes brasileiros com diagnóstico clínico de ataxia de Friedreich - 19 típicos e 6 atípicos, por PCR.

Resultados: Anormalidades sugestivas de comprometimento cerebelar, no ECG e a presença de pés cavos ocorreram com maior freqüência nos casos típicos; contudo, a resposta plantar e a fala mostraram-se mais freqüentemente normal neste grupo, quando comparados casos típicos e atípicos. A expansão GAA em homozigose foi detectada em 17 casos $(68 \%)$ - todos típicos e, em 8 (32\%) (6 atípicos e 2 típicos), não foi observada nenhuma expansão, excluindo-se o diagnóstico de ataxia de Friedreich. Deformidade de pés, anormalidades cardíacas e alguns achados neurológicos ocorreram mais freqüentemente, nos casos com expansão GAA, contudo, sinais de comprometimento dos pares cranianos e alterações dos achados tomográficos foram detectados menos frequentemente 
do que em pacientes sem expansão.

Discussão: A análise molecular é imprescindível para o diagnóstico de ataxia de Friedreich, não só para os casos típicos como também para os atípicos. Não há qualquer correlação entre o genótipo e o fenótipo. O diagnóstico baseado apenas nos achados clínicos é limitado, embora facilite a triagem para melhor selecionar os casos suspeitos que merecem ser testados. A dosagem sérica da vitamin E é recomendada, especialmente nos casos sem expansão GAA.

DESCRITORES: Ataxia de Friedreich. Expansão de trinucleotídios. Expansão GAA.

\section{REFERENCES}

1. ANDERMANN E, REMILLARD G M, GOYER C et al. - Genetic and family studies in Friedreich's ataxia. Can J Neurol Sci 1976;3:287-301

2. BARRETT T M - Friedreich's ataxia: clinical and postmortem study of two cases in brothers at different stages of the disease. Arch Neurol \& Psychiatr 1927;17:28-43.

3. BELAL S, PANAYIDES K, SIRUGO G et al. - Study of large inbred Friedreich ataxia families reveals a recombination between D9S15 and the disease locus. Am J Hum Genet 1992;51:1372-1376.

4. BELL J M \& CARMICHAEL E A - On hereditary ataxia and spastic paraplegia. In: Treasury of human inheritance. London, Cambridge Press, 1939. v.4, p.141-284. Apud ANDERMANN et al ${ }^{1}$

5. BOYER S H, CHISHOLM A W \& McKUSICK V A - Cardiac aspects of Friedreich's ataxia. Circulation 1962;25:493-505.

6. CAMPUZANO V, MONTERMINI L, MOLTÒ M D et al. - Friedreich's ataxia: autosomal recessive disease caused by an intronic GAA triplet repeat expansion. Science 1996;271:1423-1427.

7. CHAMBERLAIN S, FARRALL M, SHAW J et al - Genetic recombination events which position the Friedreich ataxia locus proximal to the D9S15/D9S5 linkage group on chromosome 9q. Am J Hum Genet 1993;52:99-109.

8. CHAMBERLAIN S, SHAW J, ROWLAND A et al. - Mapping of mutation causing Friedreich's ataxia to human chromosome 9. Nat Genet 1988;334:248-250.

9. De MICHELE G, CAVALCANTI F, CRISCUOLO C et al. - Parental gender, age at birth and expansion length influence GAA repeat intergenerational instability in the X25 gene: pedigree studies and analysis of sperm from patients with Friedreich's ataxia. Hum Mol Genet 1998;7:1901-1906.

10. DUCLOS F, RODIUS F, WROGEMANN K et al. - The Friedreich ataxia region: characterization of two novel genes and reduction of the critical region to $300 \mathrm{~kb}$. Hum Mol Genet 1994;3:909-914.
11.DÜRR A, COSSÉE M, AGID Y et al. - Clinical and genetic abnormalities in patients with Friedreich's ataxia. N Engl J Med 1996;335:1169-1175

12. DYCK P J \& LAMBERT E H - Lower motor and primary sensory neuron diseases with peroneal muscular atrophy. Arch Neurol 1968:18:619-625.

13. FILLA A, De MICHELE G, CARUSO G et al. - Genetic data and natural history of Friedreich's disease: a study of 80 Italian patients. J Neurol 1990;237:345-351, 1990.

14. FILLA A, De MICHELE G, CAVALCANTI F et al. - The relationship between trinucleotide (GAA) repeat length and clinical features in Friedreich ataxia. Am J Hum Genet 1996;59:554-560.

15. FUJITA R, AGID Y, TROUILLAS P et al. - Confirmation of linkage of Friedreich ataxia to chromosome 9 and identification of a new closely linked marker. Genomics, 1989;4:110-111.

16. GEOFFROY G, BARBEAU A, BRETON G et al. - Clinical description and roentgenologic evaluation of patients with Friedreich's ataxia. Can J Neurol Sci 1976;3:279-286.

17. HARDING A E - Friedreich's ataxia: a clinical and genetic study of 90 families with an analysis of early diagnostic criteria and intrafamilial clustering of clinical features. Brain 1981;104:589620 .

18. HEWER R L - Study of fatal cases of Friedreich's ataxia. Br Med J 1968;3:649-652.

19. KLOCKGETHER T, CHAMBERLAIN S, WÜLLNER U et al. - Lateonset Friedreich's ataxia: molecular genetics, clinical neurophysiology, and magnetic resonance imaging. Arch Neurol 1993;50:803-806

20. LAMONT P J, DAVIS M B \& WOOD N W - Identification and sizing of the GAA trinucleotide repeat expansion of Friedreich's ataxia in 56 patients: clinical and genetic correlates. Brain 1997;120:673680 . 
21. MILLER S A, DYKES D D \& POLESKY H F - A simple salting out procedure for extracting DNA from human nucleated cells. Nucleic Acids Res 1988;16:1215.

22. MONTERMINI L, RODIUS F, PIANESE L et al. - The Friedreich ataxia critical region spans a 150-kb interval on chromosome 9q13. Am J Hum Genet 1995;57:1061-1067.

23. OMIM - Online Mendelian Inheritance in man, OMIM (TM). Center for Medical Genetics, Johns Hopkins University (Baltimore, MD) and National Center for Biotechnology Information, National Library of Medicine (Bethesda, MD), 1996. World Wide Web URL: http://www.3.ncbi.nlm.nih.gov:80/htbin-post/Omim/ dispmim?277460

24. OHSHIMA K, KANG S, LARSON J E \& WELLS R D - Cloning, characterization and properties of seven triplet repeat DNA sequences. J Biol Chem 1996;271, 16773-16783.

25. PANDOLFO M \& MONTERMINI L - Molecular genetics of the hereditary ataxias. Adv Genet 1998;38:31-68.
26. RODIUS F, DUCLOS F, WROGEMANN K et al. - Recombinations in individuals homozygous by descent localize the Friedreich ataxia locus in a cloned 450-Kb interval Am J Hum Genet 1994;54:10501059 .

27. SCHÖLS L, AMOIRIDIS G, PRZUNTEK H et al. - Friedreich's ataxia: revision of the phenotype according to molecular genetics. Brain 1997;120:2131-2140.

28. SCHWARTZ I V D, JARDIM L B, PUGA AC S et al. - Clinical and molecular studies in five Brazilian cases of Friedreich ataxia. Arq Neuropsiquiatr 1999;57:1-5, 1999.

29. SINDEN R R - Human genetics '99: trinucleotide repeats. Biological implications of the DNA structures associated with disease-causing triplet repeats. Am J Hum Genet 1999;64:346-353.

30. THORÉN C - Diabetes mellitus in Friedreich's ataxia. Acta Paediatr (Stockholm) 1962; 135(suppl.):239-247.

Received for publication on February 14, 2001. 